\title{
Influence of Forest Management and Previous Herbivory on Cattle Diets
}

\author{
Kenric J. Walburger, ${ }^{1}$ Timothy DelCurto, ${ }^{2}$ and Martin Vavra ${ }^{3}$ \\ Authors are ${ }^{1}$ Assistant Professor, Department of Animal and Poultry Science, University of \\ Saskatchewan, Saskatoon, SK S7N 5A8, Canada; ${ }^{2}$ Associate Professor, Department of Animal Sciences, \\ Eastern Oregon Agriculture Research Center, Oregon State University, Union, OR 97883; and \\ ${ }^{3}$ Supervisory Rangeland Scientist, Pacific Northwest (PNW) Research Station, USDA Forest Service, \\ Forestry and Range Sciences Laboratory, La Grande, OR 97850.
}

\begin{abstract}
Grazing cattle and timber harvest are common practices associated with forested rangelands. Therefore, the objective was to document the effects of timber harvest and herbivory on nutritional quality and botanical composition of steer diets in grand fir (Abies grandis [Dougl. ex D. Don] Lindl.) and ponderosa pine (Pinus ponderosa P. \& C. Lawson) forests. Three replicated grand fir sites were arranged as a split-plot design; timber harvest treatments-1) no harvest (CON), 2) thinning (TH), 3) clearcut (CL) were whole plots, and herbivory treatments-1) large ungulate grazing (Graze), 2) wild ungulate grazing (CExc), and 3) exclusion of large ungulate grazing (TExc) - were the subplots. Three replicated ponderosa pine sites were arranged as a split-plot design; timber harvest treatments-1) CON and 2) TH-were whole plots, and herbivory treatments-1) GR, 2) BG, and 3) EX-were subplots. Diet samples were collected in June and August of 2001 and 2002. Crude protein, in vitro organic matter digestibility, acid detergent fiber, and neutral detergent fiber of the diets were only affected by season of use and were higher $(P<0.05)$ quality during the June grazing period. Botanical composition of diets was determined with the use of microhistological analysis of ruminal masticate. Within grand fir sites, graminoids were the major constituent in the diet $(65 \%-91 \%)$, forbs intermediate $(8 \%-$ $31 \%)$, and shrubs least $(0.2 \%-3.5 \%)$. Within ponderosa pine sites graminoids were the major constituent in the diet $(83 \%-88 \%)$, forbs intermediate $(10 \%-14 \%)$, and shrubs least $(2 \%-3 \%)$. Season of use did not affect $(P>0.10)$ botanical composition in either grand fir or ponderosa pine sites. Timing of grazing had a greater influence on diet quality; however, previous herbivory and(or) timber harvest had a greater influence on composition of diets than did timing of grazing.
\end{abstract}

\section{Resumen}

El apacentamiento del ganado y la cosecha de madera son prácticas comunes en los pastizales boscosos. Los objetivos de este estudio fueron documentar los efectos de la cosecha de madera y herbivoría en la composición botánica y calidad nutricional de las dietas de novillos en bosques de "grand fir" (Abies grandis [Dougl. ex D. Don] Lindl.) y "ponderosa pine" (Pinus ponderosa P. \& C. Lawson). Tres sitios repetidos de "grand fir" se arreglaron en un diseño de parcelas divididas y los tratamientos de cosecha de madera: 1) sin cosecha (CON), 2) aclareo (TH), y 3) corte (CL) fueron las parcelas principales y los tratamientos de herbivoría 1) apacentamiento de grandes ungulados (Graze), 2) apacentamiento de ungulados silvestres (CExc), y 3) la exclusión a los grandes ungulados (TExc) fueron las subparcelas. De la misma forma tres sitios repetidos de "ponderosa pine" se arreglaron en un diseño de parcelas divididas y las parcelas principales fueron los tratamientos de cosecha de madera 1) CON y 2) TH y los tratamientos de herbivoría 1) GR, 2) BG y 3) EX fueron las subparcelas. Las muestras de las dietas fueron colectadas en Junio y Agosto del 2001 y 2002 usando cuatro novillos con cánula ruminal. La proteína cruda, la digestibilidad in vitro de la materia orgánica, las fibra detergente neutro y fibra detergente ácido de las dietas fueron afectados solo por la estación de uso. Las dietas fueron de mayor calidad $(P<0.05)$ en Junio que en Agosto. La composición botánica de las dietas fue determinada usando el análisis microhistológico del bolo ruminal. Dentro de los sitios de "grand fir," las gramíneas fueron el mayor componentes de la dieta $(65 \%-91 \%)$, las hierbas fueron intermedias $(8 \%-31 \%)$ y los arbustos el componente menor $(0.2 \%-$ $3.5 \%)$. En los sitios de "ponderosa pine" las gramíneas también fueron el componente principal de la dieta (83\%-88\%), las hierbas intermedio $(10 \%-14 \%)$ y los arbustos el menor $(2 \%-3 \%)$. La época de uso no afectó $(P>0.10)$ la composición botánica ni en los sitios de "grand fir" ni en los de "ponderosa pine." La época de apacentamiento tuvo una gran influencia en la calidad de la dieta, sin embargo, la herbivoría y/o cosecha de madera previas tuvieron una mayor influencia sobre la composición de las dietas que la época de apacentamiento.

Key Words: Abies grandis, beef cattle, botanical composition, diet quality, Pinus ponderosa

At the time of research, the senior author was a Graduate Research Assistant, Eastern Oregon Agriculture Research Center, Oregon State University, Union, OR 97883.

Correspondence: Timothy DelCurto, Dept of Animal Sciences, Eastern Oregon Agriculture Research Center, Oregon State University, Union, OR 97883. Email: tim.delcurto@ oregonstate.edu.

Manuscript received 13 December 2005; manuscript accepted 20 November 2006.

\section{INTRODUCTION}

Grazing cattle and timber harvest are common practices associated with forested rangelands in North America. These areas comprise a significant portion of the public lands in the west and produce habitat and forage for livestock and wildlife, as 


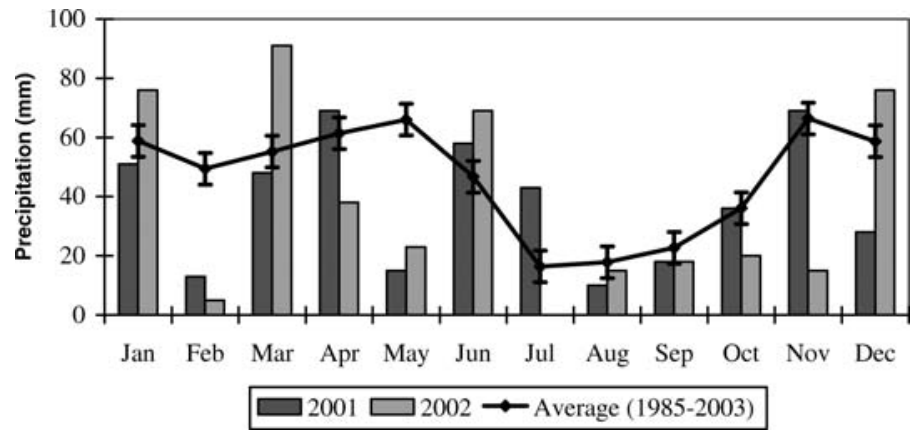

Figure 1. Precipitation data $(\mathrm{mm})$ from weather station located at Eastern Oregon Agriculture Research Center's Hall Ranch.

well as wood products for human use. However, over the past 100 years many areas with the potential for high forage production have had low outputs because of dense canopy cover (Hedrick et al. 1969). Therefore, it may be necessary to open the canopy to return the understory productivity of these lands.

Timber harvest on forested rangelands sets back succession and, in most cases, increases understory forage production (McConnell and Smith 1965, 1970; Jameson 1967; Young et al. 1967; Thompson and Gartner 1971). This results in an increased opportunity for cattle/wildlife to forage and obtain a higher-quality diet, and subsequently increases productivity. Typically, cattle select a diet that is predominantly grass with limited forbs and shrubs (Holechek et al. 1982; Mitchell and Rodgers 1985). However, cattle diets vary throughout the grazing season, with woody vegetation becoming a greater part of the diet as the grazing season progresses (Darambazar 2003; Holechek et al. 1982; Mitchell and Rodgers 1985).

Few studies have evaluated diet quality on forested rangelands over the grazing season, nor have they documented the potential effects of timber harvest, whereas more is known about changing body condition and weight change over this same period. Holechek et al. (1981, 1987), Vavra (1984), and Walburger et al. (2000) have all documented that cattle gain less in the late summer and fall when compared to late spring and early summer.

The combined effects of timber harvest and previous herbivory (wild and/or domestic ungulates) on diet quality have not been documented. Therefore, the objective of this study was to determine how timber harvest, previous herbivory, and season of use affect the quality of diets obtained from forested rangelands.

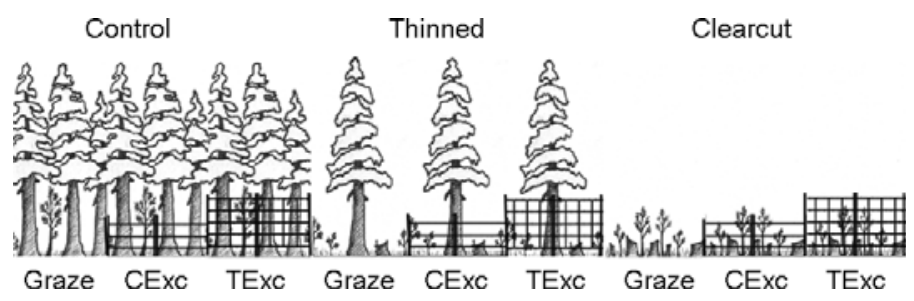

Figure 2. Layout of the timber harvest (control, thinned, and clearcut) and herbivory (Graze-cattle and big game grazing; CExc — cattle exclosure, big game grazing only; TExc-total exclosure, exclusion of cattle and big game grazing) treatments for each grand fir site.

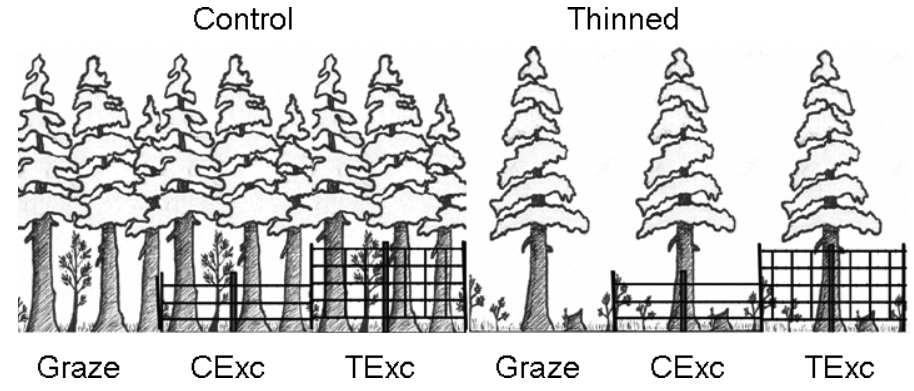

Figure 3. Layout of timber harvest (control and thinned) and herbivory (Graze — cattle and big game grazing; CExc_cattle exclosure, big game grazing only; TExc - total exclosure, exclusion of cattle and big game grazing) treatments for each ponderosa pine site.

\section{MATERIALS AND METHODS}

The study area is located at the Eastern Oregon Agriculture Research Center's Hall Ranch, which is approximately 16 km east of the city of Union in the Wallowa Mountains of northeastern Oregon. Elevation ranges from 1050 to $1250 \mathrm{~m}$ and annual precipitation averages $560 \mathrm{~mm}$ with about $65 \%$ coming in the winter, whereas summers are usually dry (Fig. 1). Cattle have been grazing the area since mid-1880. Elk (Cervus elaphus L.) and mule deer (Odocoileus hemionus Raf.) are indigenous to the area and can be found throughout the year; however, heaviest use occurs in spring and fall.

The study was conducted as a replicated split-plot design. Three Abies grandis (Dougl. ex D. Don) Lindl./Pachistima myrsintes (Pursh) Raf. (grand fir), 22.5 ha each in size, and three Pinus ponderosa P. \& C. Lawson/Symphoricarpos albus (L.) Blake (ponderosa pine), 15 ha each in size, sites were selected to analyze the effects of herbivory and overstory canopy cover on botanical composition of diets and diet quality. Sites were selected within areas of relatively homogeneous stand structure. The grand fir sites had three timber harvest treatments applied: 1) clear cut, 2) crown thinning, and 3) uncut (Control; Fig. 2). Crown thinning consisted of removing trees from the dominant and codominant crown classes in order to favor the best trees of those same crown classes. The grand fir clearcuts were replanted in the spring of 1988 with ponderosa pine, Douglas fir (Pseudotsuga menziesii [Mirbel] Franco var. glauca [Beissn.] Franco), and western larch (Larix occidentalis Nutt.). The ponderosa pine sites had 2 timber harvest treatments applied: 1) commercial thinning and 2) uncut (Control; Fig. 3). Commercial thinning is designed to capture imminent mortality due to competition and to modify the stand so that continued stand development will enhance the quality or growth of the remaining trees. Trees that were removed were large enough to be of commercial value. Thinning within the ponderosa pine sites was done to achieve a tree basal area of $24 \mathrm{~m}^{2} \cdot \mathrm{ha}^{-1}$ (tree spacing of approximately $8 \mathrm{~m}$ ). Clear cutting was not applied to ponderosa pine sites because it was not a commercially acceptable practice within the area. Timber harvest began in 1985 and was completed in 1986.

The following herbivory treatments were applied within all timber harvest treatments for both grand fir and ponderosa pine sites: 1) grazing by cattle, to achieve $60 \%$ utilization of herbaceous plant material, and big game (Grazed), 2) big game 
grazing only (Cattle exclosure), and 3) exclusion of cattle and big game grazing (Total exclosure). Sixty percent utilization is considered heavy relative to current recommendations (Holechek et al. 1995), but was used because it was considered a typical utilization level for industrial forests within the area. Cattle and total exclosures were approximately 0.5 ha in size. Grazing treatments were initiated following completion of timber harvest in 1986. Grazing by cattle was done in conjunction with allotment grazing from mid-August through October for the grand fir sites. Ponderosa pine sites were grazed in a deferred rotation grazing system. Even years were grazed from mid-June to mid-July and odd years were grazed from beginning of July to mid-August. The cattle grazing treatment in ponderosa pine sites was removed from 2001 and 2002 to allow for diet collections in mid-August.

Vegetation on these sites was varied, but the dominant graminoids were elk sedge (Carex geyeri Boott), pinegrass (Calamagrostis rubescens Buckl.), and Kentucky bluegrass (Poa pratensis L.). Numerous forbs were also found, including heartleaf arnica (Arnica cordifolia Hook.), western yarrow (Achillea millefolium L.), cinquefoil species (Potentilla spp.), and lupine species (Lupinus spp.). Several shrub species were typically found, including mallow ninebark (Physocarpus malvaceus [Greene] Kuntze), common snowberry (Symphoricarpos albus [L.] Blake), Oregon grape (Berberis repens Lindl.), and birchleaf spirea (Spiraea betulifolia Pallas). Overstory of the grand fir sites within the controls and thinned timber harvest treatments were dominated by grand fir, whereas, dominant overstory species within clearcuts was ponderosa pine, Douglas fir, and western larch; however, grand fir saplings were numerous. Overstory of the ponderosa pine sites was dominated by ponderosa pine and interspersed with western larch.

Four ruminally cannulated steers were used to determine diets in June and August of 2001 and 2002. Steers were allowed to graze pastures for several weeks before collections to become familiar with plant communities. Prior to the grazing bout, steers were transported to site and ruminally evacuated as described by Lesperance et al. (1960), except rumen walls were rinsed with a sponge to remove as much material as possible. Steers were allowed to graze for 20 minutes and grazed masticate samples were removed immediately following the grazing bout. Multiple collections were made by each steer within a day, both morning and evening collections. Launchbaugh et al. (1990) reported no differences in cattle diets between morning and evening collections. Therefore, we randomized the order that sites were grazed within each block to minimize any potential effects of an empty rumen on forage selectivity. Following collection of masticate samples, original rumen contents were replaced. Masticate samples were completely dried at $50^{\circ} \mathrm{C}$ in a forced-air oven and were ground through a Wiley mill (Thomas Scientific, Sweedesboro, NJ) with the use of a 1-mm screen. Composite samples were created for each experimental unit by combining a 50-g subsample of each steer's masticate sample. Samples were then analyzed for crude protein (CP) (AOAC 1990), acid detergent fiber (ADF), and neutral detergent fiber (NDF) with the use of the Ankom 200 Fiber Analyzer (ANKOM Technology Corporation, Fairport, $\mathrm{NY}$ ), and in vitro organic matter digestibility (IVOMD) using the Daisy II in vitro system (ANKOM Technology). Livestock were handled according to the protocol approved by the
Institutional Animal Care and Use Committee at Oregon State University.

Botanical composition of steer diets was determined with the use of microhistological analysis. Composite samples were soaked in sodium hydroxide and mounted with the use of techniques described by Holechek (1982). Three slides for each sample collected from grand fir sites and 4 slides for each sample collected from ponderosa pine sites were prepared and then dried at $55^{\circ} \mathrm{C}$ in a forced-air oven, for a minimum of 48 hours, prior to analysis. Twenty fields per slide were systematically observed at $\times 100$ magnification. Plant fragments were identified by comparing epidermal characteristics with plant species reference slides and recorded as frequency counts. Dryweight composition of each sample was determined by dividing the frequency of each species by the total number of frequencies for all species (Holechek and Gross 1982).

Herbaceous production was collected in 2003 by clipping $0.5 \times 1.0 \mathrm{~m}$ rectangular plots placed randomly within each experimental unit $(n=20)$. Plots were clipped by species to a 2 -cm stubble height. Production clips were completely dried in a forced-air oven at $50^{\circ} \mathrm{C}$ and weighed to the nearest $0.1 \mathrm{~g}$. With the use of the production data, a relative preference index (RPI) was calculated to determine the relationship between botanical composition and forage availability. Relative preference index was calculated as: $\%$ diet composition $/ \%$ forage composition (Krueger 1972). This index was used to account for the differences (data not provided) in understory forage production among the herbivory and timber harvest treatments.

All data were analyzed as a split-plot design within a randomized complete block design with 3 replications under MIXED procedures in SAS (SAS 2005) with the block (site replication) effect considered random. The whole-plot experimental unit was timber harvest treatment and the subplot experimental unit was herbivory within timber harvest treatments. Treatment means were separated with the use of LS means procedures of SAS (SAS 2005) and were considered significant at $P<0.05$.

\section{RESULTS}

\section{Grand Fir Sites}

There were no interactions $(P>0.40)$ among season of use, timber harvest, and herbivory treatments for any measures of diet quality determined; therefore, only treatment means are reported. Crude protein, IVOMD, NDF, and ADF were all affected by season of use (Table 1). Crude protein and IVOMD of steer diets were 4.5 and 6.1 percentage points, respectively, higher $(P<0.001)$ in June than in August. Only minor differences $(P \leq 0.02)$ in NDF and ADF content occurred between June and August (2.4\% and $1.4 \%$, respectively).

Timber harvest and herbivory treatments had little effect on the quality of steer diets; except for ADF. The clearcuts and thinned treatments had lower $(P \leq 0.03)$ ADF values than control treatments. This increase of ADF in the control treatments could be due to greater amount of forbs consumed by steers and/or the effects of increased canopy cover on structural characteristics of consumed forages.

Botanical composition of steer diets did not exhibit an interaction among season of use, timber harvest, and herbivory 
Table 1. The effect of season of use and timber harvest on the subsequent quality of steer diets in a grand fir forested habitat. ${ }^{1}$

\begin{tabular}{ccccccccc}
\hline & \multicolumn{3}{c}{ Season of use } & & \multicolumn{4}{c}{ Timber harvest treatment } \\
\cline { 2 - 3 } \cline { 7 - 9 } Item $^{2}$ & June & August & SE & & Clearcut & Thinned & Control & SE $^{3}$ \\
\hline CP, \% OM & $14.9 \mathrm{a}$ & $10.3 \mathrm{~b}$ & 0.3 & & 12.6 & 12.5 & 12.6 & 0.3 \\
IVOMD (\%) & $78.5 \mathrm{a}$ & $72.4 \mathrm{~b}$ & 0.5 & & 76.6 & 75.4 & 74.5 & 0.9 \\
NDF, \% OM & $55.6 \mathrm{a}$ & $58.0 \mathrm{~b}$ & 0.7 & & 57.3 & 55.8 & 57.4 & 0.6 \\
ADF, \% OM & $39.7 \mathrm{a}$ & $41.1 \mathrm{~b}$ & 0.5 & & $38.4 \mathrm{a}$ & $40.0 \mathrm{a}$ & $42.9 \mathrm{~b}$ & 0.8 \\
\hline
\end{tabular}

${ }^{1}$ Values within a row followed by different letters are different at $P<0.05$.

${ }^{2} \mathrm{CP}$ indicates crude protein; IVOMD, in vitro organic matter digestibility; NDF, neutral detergent fiber; ADF, acid detergent fiber; OM, organic matter.

${ }^{3} \mathrm{SE}$ indicates standard error.

treatment interactions $(P \geq 0.70)$. However, graminoids and forbs exhibited an interaction between timber harvest and herbivory treatments $(P=0.04$; Table 2$)$. Graminoids were also affected by season of use, with June diets having greater amount of graminoids than August diets $(83.5 \%$ and $80.4 \%$, respectively). Amount of shrubs consumed was not affected $(P \geq 0.11)$ by either season of use, timber harvest, or herbivory treatments.

Consumption of graminoids was least $(P \leq 0.02)$ in controls, across all herbivory treatments, compared to clearcuts and thinned treatments (Table 2). In addition, total exclosures within the controls had the lowest amount of graminoids in steer diets compared to grazed and cattle exclosures $(P<0.01)$. Conversely, consumption of forbs was greatest $(P \leq 0.04)$ in controls, across all herbivory treatments, compared to clearcuts and thinned treatments.

Also, RPI did not exhibit an interaction among season of use, timber harvest, and herbivory treatments $(P \geq 0.75)$. However, the RPI of graminoids and forbs within steer diets was affected $(P \leq 0.04)$ by an interaction between timber harvest and herbivory treatments. Steers showed a strong preference for graminoids in all timber harvest and herbivory treatments (Table 3). However, preference did vary within timber harvest treatments. Within clearcuts, preference for graminoids was

Table 2. The effects of timber harvest and herbivory treatments on the botanical composition (\%) of steer diets in a grand fir forested habitat. ${ }^{1,2}$

\begin{tabular}{|c|c|c|c|c|c|}
\hline & \multirow{2}{*}{$\begin{array}{c}\text { Herbivory } \\
\text { treatments }^{3}\end{array}$} & \multicolumn{3}{|c|}{ Timber harvest treatments } & \multirow[b]{2}{*}{$\mathrm{SE}^{4}$} \\
\hline & & Clearcut & Thinned & Control & \\
\hline \multirow[t]{3}{*}{ Graminoids } & Grazed & 88.31 & $82.7 \mathrm{ab} 12$ & $76.1 \mathrm{a} 2$ & \\
\hline & Cattle exc & 91.51 & 88.0 a1 & 75.8 a2 & 3.17 \\
\hline & Total exc & 90.31 & 79.4 b2 & 65.4 b3 & \\
\hline \multirow[t]{3}{*}{ Forbs } & Grazed & 10.71 & $15.6 \mathrm{ab} 1$ & $22.5 \mathrm{a} 2$ & \\
\hline & Cattle exc & 8.31 & $10.7 \mathrm{a} 1$ & $21.1 \mathrm{a} 2$ & 3.10 \\
\hline & Total exc & 9.31 & 19.6 b2 & $31.1 \mathrm{~b} 3$ & \\
\hline \multirow[t]{3}{*}{ Shrubs } & Grazed & 0.9 & 1.7 & 1.3 & \\
\hline & Cattle exc & 0.2 & 1.3 & 3.1 & 0.96 \\
\hline & Total exc & 0.4 & 0.9 & 3.5 & \\
\hline
\end{tabular}

$\overline{1}$ Values within a column within forage type followed by different numbers are different at $P<0.05$.

${ }^{2}$ Values within a row followed by different letters are different at $P<0.05$.

${ }^{3}$ Herbivory treatments: Grazed — cattle and big game grazing; Cattle exc-cattle exclosure, big game grazing only; Total exc-total exclosure, exclusion of cattle and big game grazing.

${ }^{4} \mathrm{SE}$ indicates standard error.
Table 3. The effects of timber harvest and herbivory treatments on the relative preference index (RPI) ${ }^{1}$ of graminoids, forbs, and shrubs for steer diets in a grand fir forested habitat. ${ }^{2,3}$

\begin{tabular}{llllll}
\hline & \multirow{2}{*}{$\begin{array}{l}\text { Herbivory } \\
\text { treatments }\end{array}$} & \multicolumn{3}{c}{ Timber harvest treatments } & \\
\cline { 3 - 4 } & Clearcut & Thinned & Control & SE $^{5}$ \\
\hline Graminoids & Grazed & $1.39 \mathrm{a}$ & $1.30 \mathrm{ab}$ & 1.50 & \\
& Cattle exc & $1.57 \mathrm{~b}$ & $1.39 \mathrm{a}$ & 1.42 & 0.12 \\
& Total exc & $1.32 \mathrm{a}$ & $1.18 \mathrm{~b}$ & 1.51 & \\
Forbs & Grazed & 0.90 & $1.14 \mathrm{a}$ & $1.08 \mathrm{a}$ & \\
& Cattle exc & 0.55 & $0.84 \mathrm{a}$ & $1.53 \mathrm{~b}$ & 0.34 \\
& Total exc & 0.701 & $1.94 \mathrm{~b} 2$ & $2.00 \mathrm{c} 2$ & \\
\multirow{3}{*}{ Shrubs } & Grazed & 0.03 & 0.09 & 0.05 & \\
& Cattle exc & 0.02 & 0.08 & 0.11 & 0.04 \\
& Total exc & 0.03 & 0.05 & 0.10 & \\
\hline
\end{tabular}

${ }^{1} \mathrm{RPI}=\%$ diet composition/\% forage composition (Krueger 1972).

${ }^{2}$ Values within a column within forage type followed by different numbers are different at $P<0.05$.

${ }^{3}$ Values within a row followed by different letters are different at $P<0.05$.

${ }^{4}$ Herbivory treatments: Grazed — cattle and big game grazing; Cattle exc—cattle exclosure, big game grazing only; Total exc-total exclosure, exclusion of cattle and big game grazing. ${ }^{5} \mathrm{SE}$ indicates standard error.

greatest $(P \leq 0.04)$ in cattle exclosures. Within controls, graminoids were preferred and not different among all grazing treatments. In clearcuts, steers selected forbs in proportion to availability, but in the thinned treatment, steers preference for forbs was greatest $(P=0.01)$ in the total exclosure compared to either the grazed or cattle exclosures. Steers also showed a preference for forbs in the cattle and total exclosures of control (no timber harvest) treatments (1.53 and 2.00, respectively). Shrubs, on the other hand, were not preferred $(P \geq 0.23)$ in the timber harvest or herbivory treatments.

Total understory production and graminoid production in 2003, 18 years post-harvest, was only affected $(P \leq 0.05)$ by timber harvest treatments (Table 4). Total understory production was greater in the clearcuts compared to both thinned and controls, 353 and $591 \mathrm{~kg} \cdot \mathrm{ha}^{-1}$ greater, respectively. Graminoid production was $540 \mathrm{~kg} \cdot \mathrm{ha}^{-1}$ greater $(P=0.02)$ in clearcuts compared to controls. Thinned treatments tended $(P=0.09)$ to be greater than controls but were not different $(P=0.22)$ from clearcuts. Production of forbs and shrubs were not affected $(P \geq 0.61)$ by either timber harvest or herbivory.

\section{Ponderosa Pine Sites}

There were no interactions $(P>0.11)$ among season of use, timber harvest, and herbivory treatments for any measures of

Table 4. The effects of timber harvest on understory production $\left(\mathrm{kg} \cdot \mathrm{ha}^{-1}\right), 18$ years post-harvest, in a grand fir forest in northeastern Oregon. ${ }^{1}$

\begin{tabular}{lcccr}
\hline & Clearcut & Thinned & Control & SE $^{2}$ \\
\hline Total production & $1423 \mathrm{a}$ & $1070 \mathrm{~b}$ & $832 \mathrm{~b}$ & 94 \\
Graminoids & $947 \mathrm{a}$ & $736 \mathrm{ab}$ & $407 \mathrm{~b}$ & 118 \\
Forbs & 246 & 175 & 178 & 64 \\
Shrubs & 242 & 205 & 224 & 39 \\
\hline
\end{tabular}

${ }^{1}$ Values within a row followed by different letters are different at $P<0.05$.

${ }^{2} \mathrm{SE}$ indicates standard error. 
Table 5. The effects of season of use on the diet quality of steers grazing a ponderosa pine forested habitat. ${ }^{1}$

\begin{tabular}{lcrc}
\hline & \multicolumn{2}{c}{ Season of use } & \\
\cline { 2 - 3 } Item $^{2}$ & June & August & SE $^{3}$ \\
\hline CP, \% OM & $13.7 \mathrm{a}$ & $9.8 \mathrm{~b}$ & 0.28 \\
IVOMD (\%) & $80.2 \mathrm{a}$ & $74.5 \mathrm{~b}$ & 0.45 \\
NDF, \% OM & $53.5 \mathrm{a}$ & $59.2 \mathrm{~b}$ & 0.65 \\
ADF, \% OM & $35.2 \mathrm{a}$ & $38.8 \mathrm{~b}$ & 0.50 \\
\hline
\end{tabular}

${ }^{1}$ Values within a row followed by different letters are different at $P<0.05$.

${ }^{2} \mathrm{CP}$ indicates crude protein; IVOMD, in vitro organic matter digestibility; NDF, neutral detergent fiber; ADF, acid detergent fiber; OM, organic matter.

${ }^{3} \mathrm{SE}$ indicates standard error.

diet quality determined; therefore, only treatment means are reported. Neither timber harvest nor herbivory treatments influenced $(P>0.10)$ diet quality. Crude protein, IVOMD, NDF, and ADF were only affected by season of use (Table 5), with the higher quality diets occurring in June compared to August. Crude protein and IVOMD were 3.9 and 5.7 percentage points, respectively, higher $(P<0.001)$ in June than in August. In contrast, ADF and NDF content were 3.6 and 5.7 percentage points, respectively, lower $(P \leq 0.01)$ in June than in August.

There were no interactions $(P \geq 0.21)$ among season of use, timber harvest, and herbivory treatments on the botanical composition of diets; therefore, only treatment means are reported. Neither season of use nor timber harvest treatments affected $(P \geq 0.28)$ the botanical composition of steer diets, but the amount of graminoids and forbs in the steer diets was affected $(P \leq 0.04)$ by herbivory treatments. Greater than $80 \%$ of the steer diets (Table 6) was graminoids, however, the diets from cattle exclosures contained $5.2 \%$ and $4.3 \%$ more $(P \leq 0.04)$ graminoids than the grazed and total exclosures, respectively. Composition of forbs in the diets was greater $(P=0.01)$ in the grazed pasture than in the cattle exclosure, and the total exclosure tended to be greater $(P=0.08)$ than the cattle exclosure.

There were no interactions $(P \geq 0.11)$ among season of use, timber harvest, and herbivory treatments on the RPI for graminoids, forbs, and shrubs of steer diets; therefore, only treatment means are reported. Neither season of use nor timber harvest treatments affected $(P \geq 0.13)$ the RPI for graminoids, forbs, or shrubs in steer diets, but the RPI for graminoids and forbs in steer diets were affected $(P \leq 0.02)$ by herbivory treatments. Steers preferred a diet that was dominated by graminoids (Table 6); however, preference was greater $(P<0.001)$ in the total exclosure than in either the grazed or cattle exclosures. Overall, steer diets were proportionally lower in forbs or shrubs than available in the pastures. However, steer diets in the total exclosures had greater $(P \leq 0.03)$ RPI for forbs than either the grazed or cattle exclosures. In contrast, cattle grazing the total exclosures had lower $(P \leq 0.02)$ RPI for shrubs than the grazed treatments and tended to have lower RPI $(P=0.07)$ than the cattle exclosures.

Total understory production tended $(P=0.08)$ to be greater in thinned treatments compared to controls (Table 7). Also, production of forbs was $144 \mathrm{~kg} \cdot \mathrm{ha}^{-1}$ greater $(P=0.001)$ in thinned treatments compared to controls. Herbivory treatments
Table 6. The effects of herbivory on the botanical composition (\%) and relative preference index $(\mathrm{RPI})^{1}$ of steer diets within a ponderosa pine forest type. ${ }^{2}$

\begin{tabular}{lcccc}
\hline & \multicolumn{3}{c}{ Herbivory treatments $^{3}$} & \\
\cline { 2 - 4 } & Grazed & Cattle exc & Total exc & SE $^{4}$ \\
\hline Botanical composition & & & & \\
Graminoids & $83.2 \mathrm{a}$ & $88.4 \mathrm{~b}$ & $84.1 \mathrm{a}$ & 2.75 \\
Forbs & $14.3 \mathrm{a}$ & $9.9 \mathrm{~b}$ & $13.1 \mathrm{ab}$ & 2.64 \\
Shrubs & 2.5 & 1.7 & 2.9 & 0.40 \\
RPI & & & & \\
Graminoids & $1.28 \mathrm{a}$ & $1.28 \mathrm{a}$ & $1.50 \mathrm{~b}$ & 0.15 \\
Forbs & $0.54 \mathrm{a}$ & $0.51 \mathrm{a}$ & $0.81 \mathrm{~b}$ & 0.15 \\
Shrubs & $0.38 \mathrm{a}$ & $0.27 \mathrm{ab}$ & $0.15 \mathrm{~b}$ & 0.10 \\
\hline
\end{tabular}

${ }^{1} \mathrm{RPI}=\%$ diet composition/\% forage composition (Krueger 1972).

${ }^{2}$ Values within a row followed by different letters are different at $P<0.05$.

${ }^{3}$ Grazing treatments: Grazed—cattle and big game grazing; Cattle exc—cattle exclosure, big game grazing only; Total exc-total exclosure, exclusion of cattle and big game grazing. ${ }^{4} \mathrm{SE}$ indicates standard error.

only influenced the production of shrubs. Shrub production of total exclosures was greater than grazed and cattle exclosures, 128 and $105 \mathrm{~kg} \cdot \mathrm{ha}^{-1}$, respectively. Graminoid production was not affected $(P \geq 0.18)$ by either timber harvest or herbivory treatments.

\section{DISCUSSION}

Quality of diets collected from grand fir and ponderosa pine sites declined in late June to mid-August irrespective of timber harvest and herbivory treatments. Even though nutritional quality of these diets was declining, the quality of diets obtained in August was sufficient to meet the requirements for lactating cattle during this period (NRC 1996). Declining quality of cattle diets is a result of declining forage quality and (or) declining quantity of desirable forages. Skovlin (1967), Cook and Harris (1968), and Clark (2003), have reported that plant quality declines with increasing plant phenology and as the grazing season progresses, with grass quality declining the greatest. However, shrubs and forbs typically remain higher in quality and are able to maintain that quality throughout the summer.

Table 7. The effects of timber harvest on understory production $\left(\mathrm{kg} \cdot \mathrm{ha}^{-1}\right), 18$ years post-harvest, in a ponderosa pine forest in northeastern Oregon. ${ }^{1}$

\begin{tabular}{|c|c|c|c|c|c|c|c|}
\hline & \multicolumn{3}{|c|}{ Timber harvest treatments } & \multicolumn{4}{|c|}{ Herbivory treatments ${ }^{2}$} \\
\hline & Thinned & Control & SE & Graze & Cattle Exc & Total Exc & $\mathrm{SE}^{3}$ \\
\hline Total production & 1111 & 873 & 237 & 974 & 1016 & 988 & 237 \\
\hline Graminoids & 634 & 536 & 115 & 568 & 652 & 535 & 120 \\
\hline Forbs & $275 \mathrm{a}$ & $131 b$ & 50 & 206 & 187 & 216 & 52 \\
\hline Shrubs & 160 & 125 & 85 & $92 \mathrm{a}$ & $115 \mathrm{a}$ & $220 \mathrm{~b}$ & 84 \\
\hline
\end{tabular}

${ }^{1}$ Values within a row followed by different letters are different at $P<0.05$.

${ }^{2}$ Grazing treatments: Grazed—cattle and big game grazing; Cattle exc—cattle exclosure, big game grazing only; Total exc-total exclosure, exclusion of cattle and big game grazing. ${ }^{3} \mathrm{SE}$ indicates standard error. 
Svejcar and Vavra (1985) speculated that decreasing canopy cover increases the amount of sunlight reaching the soil surface, thereby increasing the soil temperature and reducing the available soil moisture later in the summer; as a result, plant phenology is accelerated and forage quality reduced. However, Dealy (1966), McEwen and Dietz (1965), and Severson and Uresk (1988) were unable to detect differences in CP due to changes in overstory canopy cover in ponderosa pine forests. As well, Regelin et al. (1974) found no differences in CP content in various understory species within a mixed-conifer forest. Our results indicate that the change in overstory canopy cover did not affect the quality of diets because there were no interactions with season of use and timber harvest treatment, nor were there any interactions with season of use and timber harvest treatment in the botanical composition of diets. Therefore, cattle in this study were selecting compositionally similar diets in June and August and quality of diets was not changing as a result of timber harvest treatment in August. We speculate that decreased canopy cover did not allow increased amounts of sunlight to reach the soil surface because of increased understory vegetation; as a result plant phenology of consumed forage species is slowed, which leads to higher forage qualities lasting later into the year.

Within this study, steer diets, for grand fir and ponderosa pine sites, were dominated by grasses, $65 \%-90 \%$ of the diet, forb composition was intermediate, $8 \%-31 \%$ of the diets, and shrub consumption was minimal, $\leq 3.5 \%$ of diets. The changes in composition within these diets, especially for grand fir sites, were likely due to changes in understory production. The ability of steers to obtain a diet high in grasses, a preferred constituent, in control treatments of grand fir sites would be more difficult than in clearcuts because graminoid production was $591 \mathrm{~kg} \cdot \mathrm{ha}^{-1}$ less compared to thinned and clearcut treatments. Therefore, composition of diets, to a great extent, reflected the steer's ability to obtain desired forage components.

Unexpectedly, season of use was not an influencing factor on botanical composition or preference. Torstenson et al. (2006), in northwestern Wyoming, and Beck and Peek (2005), in northeastern Nevada, also reported that cattle diets are dominated by grasses and forbs with minimal inputs from shrubs. However, Mitchell and Rodgers (1985), in a Douglas-fir/ninebark habitat type in northern Idaho, reported cattle had similar composition of diets from mid-June through August, but the diets were dominated by grasses and browse. Other researchers (Holechek 1982; Uresk and Paintner 1985) have reported changes in diet composition during this time period of mid-June through August. Holechek et al. (1982), in eastern Oregon, reported that cattle diets were composed primarily of grass but it varied among seasons, with consumption of browse increasing with progression of the grazing season. They also reported that consumption of forbs declined through the grazing period and were minor constituents in the diet. Uresk and Paintner (1985), in the Black Hills, reported that consumption of grasses and shrubs were similar throughout the grazing period and constituted approximately $54 \%$ and $28 \%$ of the diet, respectively, whereas consumption of forbs declined throughout the grazing period and only averaged $17 \%$ over the grazing season. The probable reason for the differences in diets was that the other studies (Holechek 1982; Mitchell and Rodgers 1985; Uresk and Paintner 1985) allowed grazing to continue throughout the duration of the seasonal collection periods, which, in turn, may reflect changes in forage availability. In fact, Launchbaugh et al. (1990) reported that cattle diets differed depending on when during the grazing period they were sampled. Whereas this study only allowed the grazing treatment to be applied after collections were completed, therefore, these diets represent what cattle could select if forage availability was not limited.

\section{MANAGEMENT IMPLICATIONS}

Cattle grazing on forested rangelands have the ability to select a diet that has sufficient quality to meet their nutritional requirements. In this study, timber harvest and previous herbivory had no effects on the quality of diets that cattle were able to select. Season of use was the only influence on diet quality; even though diet quality was declining it was sufficient to prevent weight loss in a lactating cow. Cattle grazing forested rangelands in northeastern Oregon preferred a diet that was dominated by graminoids. However, as graminoid production decreases, such as in heavily timbered areas, cattle will increase consumption of forbs. Shrubs occurred considerably less in the diets and forbs occurred in proportions similar to those available on the rangeland. Therefore, managers within recently timber harvested areas should initially expect cattle to avoid consuming woody vegetation, and possibly observe improved gains due to the increased forage production while quality remains unchanged.

\section{LITERATURE CITED}

[AOAC] Association of Official Analytical Chemists. 1990. Official methods of analysis. 15th ed. Arlington, VA: AOAC. $1298 \mathrm{p}$

BECK, J. L., AND J. M. PeEK. 2005. Diet composition, forage selection, and potential for forage competition among elk, deer, and livestock on aspen-sagebrush summer range. Rangeland Ecology and Management 58:135-147.

CLARK, P. E. 2003. Date and plant community effects on elk sedge forage quality. Journal of Range Management 56:13-20.

Cook, C. W., And L. E. Harris. 1968. Nutritional value of seasonal ranges. Utah Agricultural Experiment Station Bulletin. $472 \mathrm{p}$.

DarambazAR, E. 2003. Factors influencing diet composition of beef cattle grazing mixed conifer mountain riparian areas [thesis]. Corvallis, OR: Oregon State University. $116 \mathrm{p}$.

Dealy, J. E. 1966. Bitterbrush nutritional levels under natural and thinned ponderosa pine. Forest Service Research Note PNW-33. Portland, OR: US Dept of Agriculture, Pacific Northwest Forest and Range Experiment Station. 6 p.

Hedrick, D. W., B. R. Eller, J. A. B. McArthur, and R. D. Pettit. 1969. Steer grazing on mixed coniferous forest ranges in northeastern Oregon. Journal of Range Management 22:322-325.

HoLECHEK, J. L. 1982. Sample preparation techniques for microhistological analysis. Journal of Range Management 35:267-268.

Holechek, J. L., T. J. BerRy, and M. Vavra. 1987. Grazing system influences on cattle performance on mountain range. Journal of Range Management 40: $55-59$.

HolecheK, J. L., AND B. D. Gross. 1982. Evaluation of different calculation procedures for microhistological analysis. Journal of Range Management 35:721-723.

Holechek, J. L., R. D. Pieper, and C. H. Herbel. 1995. Range management: Practices and principles. 2nd ed. Englewood Cliffs, NJ: Prentice Hall. p 195-196.

HolecheK, J. L., M. VavRa, and J. Skovlin. 1981. Diet quality and performance of cattle on forest and grassland range. Journal of Animal Science 53:291-298. 
Holechek, J. L., M. Vavra, J. Skovlin, and W. C. Krueger. 1982. Cattle diets in the blue mountains of Oregon. II. Forests. Journal of Range Management 35:239-242.

JAMESON, D. A. 1967. The relationship of tree overstory and herbaceous understory vegetation. Journal of Range Management 20:247-249.

Krueger, W. C. 1972. Evaluating animal forage preference. Journal of Range Management 6:471-475.

Launchbaugh, K. L., J. W. Stuth, and J. W. Holloway. 1990. Influence of range site on diet selection and nutrient intake of cattle. Journal of Range Management 43:109-115.

Lesperance, A. L., V. R. Bohman, and S. W. Marble. 1960. Development of techniques for evaluating grazed forage. Journal of Dairy Science 43:682-689.

McConnell, B. R., AND J. G. Smith. 1965. Understory response three years after thinning pine. Journal of Range Management 18:129-132.

McConnell, B. R., AND J. G. Smith. 1970. Response of understory vegetation to ponderosa pine thinning in eastern Washington. Journal of Range Management 23:208-212.

McEwen, L. C., And D. R. Dietz. 1965. Shade effects on chemical composition of herbage in the Black Hills. Journal of Range Management 18:184-190.

Mitchell, J. E., And R. T. Rodgers. 1985. Food habits and distribution of cattle on a forest and pasture range in northern Idaho. Journal of Range Management 38:214-220.

[NRC] National Research Councli. 1996. Nutrient requirements of beef cattle. 7th ed. Washington, DC: National Academy Press. 242 p.

Regelin, W. L., O. C. Wallmo, J. Nagy, and D. R. Dietz. 1974. Effect of logging on forage values for deer in Colorado. Journal of Forestry 72:282-285.

SAS InStitute, Inc. [COMPUTER PRogram]. 2005. Statistical Analysis Systems, Version 8. Cary, NC: SAS Institute, Inc.
Severson, K. E., and D. W. Uresk. 1988. Influence of ponderosa pine overstory on forage quality in the Black Hills, South Dakota. Great Basin Naturalist 48:78-82.

SkovLIN, J. 1967. Fluctuations in forage quality on summer range in the Blue Mountains. Research Paper PNW-44. Portland, OR: US Dept of Agriculture, Forest Service PNW Forest and Range Experiment Station. 20 p.

SveJCAR, T., AND M. VavRA. 1985. The influence of several range improvements on estimated carrying capacity and potential beef production. Journal of Range Management 38:395-399.

Thompson, W. W., and F. R. Gartner. 1971. Native forage response to clearing low quality ponderosa pine. Journal of Range Management 24:272-277.

Torstenson, W. L. F., J. C. Mosley, T. K. Brewer, M. W. Tess, and J. E. Knight. 2006 Elk, mule deer, and cattle foraging relationships on foothill and mountain rangeland. Rangeland Ecology and Management 59:80-87.

Uresk, D. W., and W. W. Paintner. 1985. Cattle diets in a ponderosa pine forest in the northern Black Hills. Journal of Range Management 38:440-442.

VavRA, M. 1984. Livestock production possibilities on streamside meadows. Proceedings of Pacific Northwest Range Management Short Course. Range watersheds, riparian zones, and economics: interrelationships in management and use. Corvallis, OR: Oregon State University. p 35-44.

Walburger K., T. DelCurto, M. Vavra, L. Bryant, and J. G. Kie. 2000. Influence of a grazing system and aspect, north vs. south, on the nutritional quality of forages, and performance and distribution of cattle grazing forested rangelands. Proceedings of the Western Section, American Society of Animal Sciences. p 181-184.

Young, J. A., D. W. Hedrick, and R. F. Keniston. 1967. Forest cover and logging. Journal of Forestry 65:807-813. 